\title{
Ganglioglioma with lytic skull lesions: a case report
}

\author{
D. Gurkanlar; *H. Kocak; **E. Yucel; *A. Aciduman; *A. Gunaydin; ***Ö. Ekinci and **S. Keskil
}

Mustafa Kemal University. Medical Faculty. Department of Neurosurgery. Antakya. Turkey. *Social Security Insurance Specialization Education Hospital. Neurosurgery Clinic. Ankara. Turkey. **Kırıkkale University. Medical Faculty. Department of Neurosurgery, Kırıkkale. Turkey. ***Gazi University. Medical Faculty. Department of Pathology. Ankara. Turkey.

\section{Summary}

Gangliogliomas represent only $0.4 \%$ of central nervous system neoplasms and $1.3 \%$ of brain tumors. They are benign neoplasms with low morbidity and mortality and the patients usually present with seizures, but there has been no adult ganglioglioma with lytic skull lesion.

A 49-year-old right handed woman suffering from generalized epileptic seizures was admitted to our hospital. She had also left hemiparesis with 4/5 motor strength. Magnetic resonance imaging and immunohistochemical studies revealed WHO Grade II ganglioglioma. Skull X-ray showed the lytic skull lesions.

We have to consider gangliogliomas in the differential diagnosis of lytic skull lesions.

KEY WORDS: Ganglioglioma. Lytic skull lesions. Sinaptophysin

Ganglioglioma con lesiones líticas en el cráneo: caso clínico

\section{Resumen}

Los gangliocitomas representan sólo el 0'4\% de los tumores del sistema nervioso y el 1'3\% de los tumores cerebrales. Son tumores benignos con baja mortalidad y morbilidad y los pacientes solían presentarse con crisis comiciales. Nunca se ha presentado un ganglioglioma en el adulto acompañado de lesión lítica craneal.

Presentamos el caso de una mujer de 49 años, diestra, que había presentado crisis generalizadas con hemiparesia izquierda. La RM y el estudio histopatológico mostraron un ganglioglioma grado II en la clasificación de la OMS y las Rx de cráneo revelaron lesiones líticas, por lo que consideramos que este tumor debe entrar en la lista del diagnóstico diferencial de las lesiones líticas craneales.

Recibido; 03-06-05. Aceptado: 29-09-05
PALABRAS CLAVE: Ganglioglioma. Lesión lítica craneal. Sinaptofisina.

\section{Introduction}

Gangliogliomas were first described by Perkins in 1926 as a distinct type of benign intracranial neoplasms ${ }^{18}$. Gangliogliomas are rare tumors of the central nervous system including variable portions of neuronal and glial elements. They represent only $0.4 \%$ of central nervous system (CNS) neoplasms and $1.3 \%$ of brain tumors ${ }^{11}$.

These tumors are mostly found in temporomesial area $^{9,10,14}$, and usually in children and adults under 30 years of age ${ }^{4,8,13}$. They are known as slow growing benign neoplasms with low morbidity and mortality. Majority of the patients present with chronic intractable seizures ${ }^{12,16}$.

Herewith we report a case of supratentorial ganglioglioma having similar specialities with the literature, but unique with its lytic skull lesions. According to our knowledge there is no adult ganglioglioma with lytic skull lesions in the literature.

\section{Case report}

A 49-years-old right handed woman suffering from seizures was admitted to our hospital. She had generalized epileptic seizures for four years and her seizures were of intractable character since one year. She had also left hemiparesis with $4 / 5$ motor strength.

In 1999, her Magnetic Resonance Imaging (MRI) revealed an irregular bordered right sided frontoparietal intra-axial lesion with surrounding gliosis and edema. The lesion had mass effect but there was no obvious contrast enhancement (Figure 1 A). Her EEG revealed an epileptiform activity in the right parietotemporal regions. In 2000 contrast enhancement was seen in axial T1 weighted images (WI). In 2002, her MRI revealed an isointense right

Abreviaturas. CNS: central nervous system. CSF: cerebro spinal fluid. EEG: electroencephalogram. MRI: magnetic resonance imaging. OMS: organización mundial de la salud. RM: resonancia magnética. WHO: world health organization. 


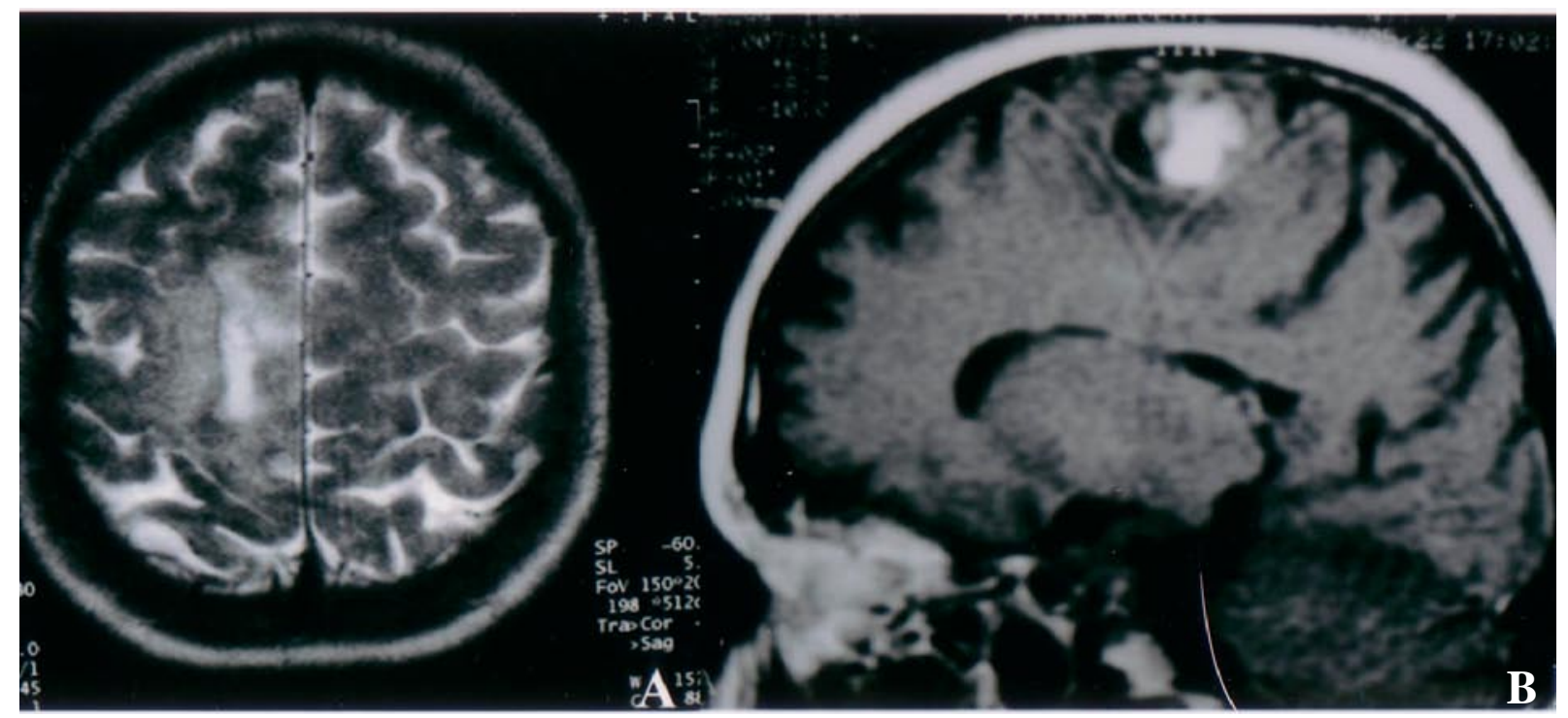

Figure 1 A, B. Axial T2-weighted MRI reveals a right sided frontoparietal intra axial lesion with surrounding gliosis and edema in 1999 (A).Parasagittal frontoparietal $2.5 \mathrm{~cm}$. mass on T1-weighted MRI in 2002(B).

sided parasagittal frontoparietal mass, $2.5 \mathrm{~cm}$. in diameter on T1WI. The tumor showed marked enhancement on T1WI. There was also a cyst-like area having a signal intensity similar to cerebrospinal fluid (CSF) on T1WI and this intensity was higher than CSF on T2WI (Figure $1 \mathrm{~B}$ ).

The skull X-rays in 2004 revealed lytic lesions located on the right frontal and the parietal bone (Figure 2). Her recent MRI revealed an isointense right sided parasagittal frontoparietal mass which had enlarged to $5 \mathrm{~cm}$. in diameter on T1WI. The tumor showed marked contrast enhancement onT1WI. There was also a cyst-like area with signal intensity similar to CSF on T1WI and higher than CSF on T2WI (Figure 3).

The patient was operated upon under general anaesthesia. There were lytic skull lesions on the parietal and frontal bones, the tumor was found over the dura mater while des-

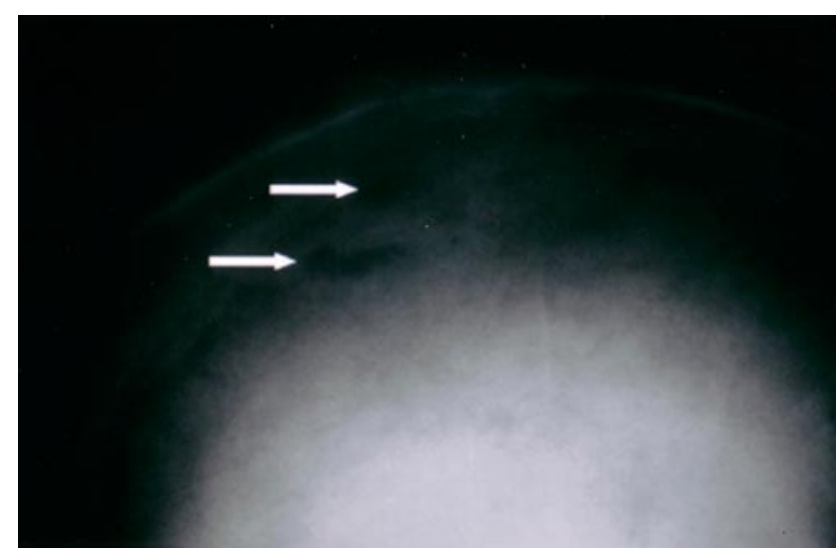

Figure 2. PA cranial X-ray graph reveals lytic skull lesions (white arrows).

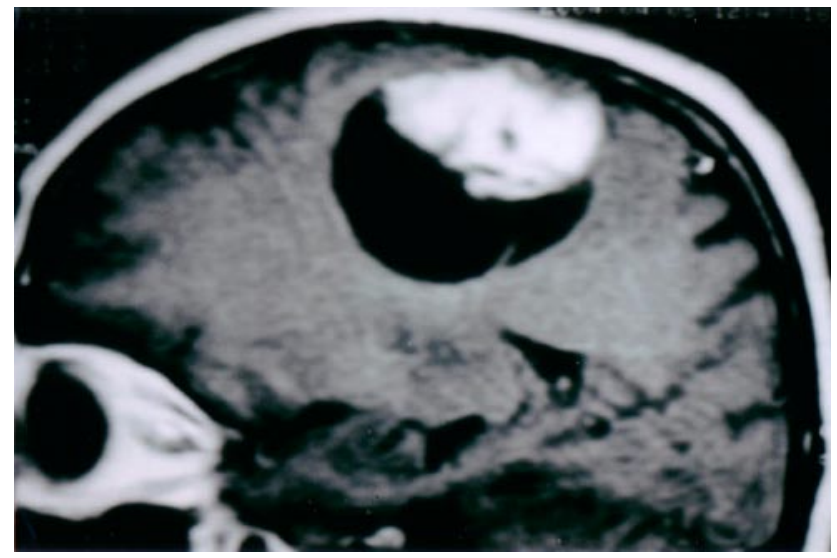

Figure 3. T1-weighted MRI reveals a frontoparietal mass, 5 $\mathrm{cm}$. in diameter with a cyst-like area.

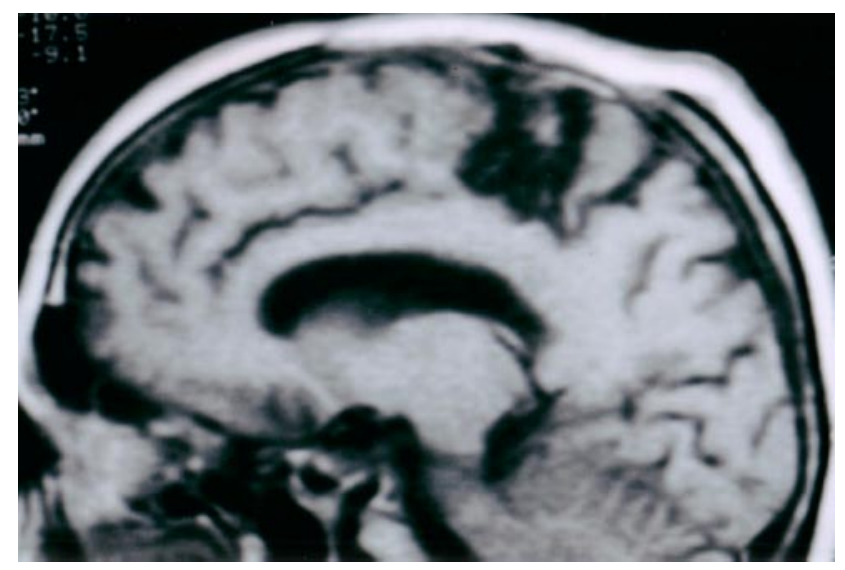

Figure 4. Follow-up MRI reveals no residual tumor. 
tructing the parietal bone. The tumor had two components: at the centre of the tumor there was a semi-solid part which was gray in colour and around this semi-solid part there was a yellowish, solid part that had irregular borders. The tumor and the dura overlying the tumor were resected totally including the cyst like portion, but we have to underline that, the tumor had a semi-solid character and the cyst like portion was not fluid in fact, it had a solid character.

The histopathology revealed WHO Grade II ganglioglioma. There was a mixture of low grade astrocytic and ganglionic elements as observed by hematoxyline and eosin staining. We used sinaptophysin as an immunohistochemical marker to identify the ganglion cells and glial fibrillary acidic protein (GFAP) to identify astrocytic elements.

It has been seven months since the surgery and the cranial MRI revealed no residual tumor (Figure 4) and the patient who has slight left sided hemiparesis can walk without any help and is free of seizures.

\section{Discussion}

Although gangliogliomas are slow growing benign neoplasms with both low morbidity and mortality ${ }^{12,16}$ early diagnosis and effective treatment is necessary since gangliogliomas most commonly affect children and young adults 9 . They can be found in any part of the CNS but they are most commonly seen in temporal and then in the frontal regions. They most commonly present with seizures $^{4,7,8,13,15,20}$ and $62,5 \%$ have seizures as the only presenting symptom $^{8}$. Once the tumor is resected, good seizure outcome is expected in patients with gangliogliomas, despite years of medically intractable epilepsy ${ }^{9}$.

Gangliogliomas are frequently found to be calcified and cystic, showing contrast enhancement on both Computerized Tomography (CT) and MRI. The tumor matrix is often isodense or hyperdense in the pre-contrast CT. Better contrast enhancement can be seen both in the solid tumors and the anaplastic type ${ }^{3,13,21,22}$. Tampier et al. ${ }^{20}$ preferred to use the term, "cyst-like" to describe the appearance on MRI of a well-defined area with signal intensity similar to CSF on protein density weighted images and higher than CSF on T2WI. This term is preferable since the content of the lesion is not fluid but solid, and therefore it cannot be drained but has to be removed.

Clear histopathological definition of gangliogliomas may be difficult. Confirmation requires the use of immunohistochemical markers, including sinaptophysin as an immunohistochemical marker for ganglionic cells and neurofilament proteins ${ }^{8}$.

Our case also presented with a history of seizure, but contrary to the literature she was over 30 years old, had a mass with frontoparietal localisation and in spite of the better contrast enhancement she had a WHO Grade II (atypical) semi-solid ganglioglioma. Primary diagnoses of atypical ganglioglioma (WHO Grade II) and anaplastyc ganglioglioma (WHO Grade III) are rare and have not yet been described sufficiently by the WHO classification system of CNS tumors ${ }^{2,6,5,19}$. Luyken et al. stated that, WHO Grade II and III lesions are associated with greater risk of recurrence or malignant progression. Such patients (like our patient) should be considered for long-term clinical follow-up using MRI ${ }^{14}$.

In addition to the afore mentioned properties, our case differs from the present literature due to the lytic skull lesions. Although Okamoto et al. ${ }^{17}$ reported thinning of the inner table of the skull in a child and Bradley et al. ${ }^{1}$ reported bony invasion of the bilateral squamous bone in a child with exophytic spicules; up to the best of our knowledge this is the first ganglioglioma throughout the literature with lytic skull lesions in an adult patient. The lytic skull lesions could be seen on X-ray graphies and contrast enhanced T1WI showed both dural invasion and invasion of the calvarial bone.

\section{Conclusion}

Many specialities of gangliogliomas have been discussed in the literature, but their osteolytic activity has never been mentioned in an adult patient. Thus, we have to consider gangliogliomas in the differential diagnosis of lytic skull lesions.

\section{References}

1. Bradley, J.P., Kure, K., Kawamoto, H.K.: Bitemporal Ganglioglioma: Surgical Management of an unusual intracranial and extracranial tumor. Plastyc Reconstr Surg. June; 2003; 111: 2328-2332.

2. Campos, M.G., Zentne,r J., Ostertun, B., Wolf, H.K., Schramm, J.: Anaplastic Ganglioglioma: Case Report and Review of the Literature. Neuro Res. 1994; 16: 317-320.

3. Castillo, M., Davis, P., Takei, Y., Hoffman, J.C.: Intracranial Ganglioglioma: MR, CT and Clinical Findings in 18 Patients. AJNR Am J Neuroradiol 1990; 11: 109-114.

4. Celli, P., Scarpinati, M., Nardacci, B., Cervoni, L., Cantore, G.P.: Gangliogliomas of the cerebral hemispheres. Report of 14 cases with long-term follow-up and review of the literature. Acta Neurochir (Wien) 1993; 125: 52-57.

5. Dash, R.C., Provenzale, J.M., McComb, R.D., Perry, D.A., Longee, D.C., McLendon, R.E.: Malignant Supratentorial Ganglioglioma (ganglion cell-giant cell glioblastoma): A Case Report and Review of the Literature. Arch Pathol Lab Med. 1999; 123: 342-345.

6. Demearel, P., Droessaert, M., Lammens, M., et al.: Anaplastic (malignant) Ganglioglioma Arising From Heterotopic Grey Matter Nodules. J Neuroonc. 1996; 30: 237-242.

7. Demierre, B., Stichnoth, F.A., Hori, A., Spoerri, O.: 
Intracerebral ganglioglioma. J Neurosurg 1986; 65: 177-182.

8. Hakim, R., Loeffler, J.S., Anthony, D.C., Black, P.M.: Gangliogliomas in Adults. Cancer January, 1997; 79: 127-131.

9. Im, S-H., Chung, C.K., Cho, B-K., Lee, S.K.: Supratentorial Ganglioglioma and Epilepsy: Postoperative Seizure Outcome. Journal of Neuro-Oncology 2002; 57: 59-66.

10. Johannsson, J.H., Rekate, H.L., Roessman, U.: Gangliogliomas. Pathological and Clinical Correlation. J Neurosurg 1981; 54: 58-63.

11. Kalyan-Raman, U.P., Olivero, W.C.: Ganglioglioma: A Correlative Clinicopathological and Radiological Study of Ten Surgically Treated Patients with Follow-Up. Neurosurgery 1987; 20: 428-433.

12. Khajavi, K., Comair, Y.G., Prayson, R.A., Wyllie, E., Palmer, J., Estes, M.L., Hahn, J.F.: Childhood Ganglioglioma and Medically Intractable Epilepsy. Pediatr Neurosurg 1995; 22: 181-188.

13. Krouwer, H.G., Davis, R.L., McDermott, M.W., Hoshino, T., Prados, M.: Gangliogliomas. A clinicopathological study of 25 cases and review of the literature. J Neuro Oncol 1993; 17: 139-154.

14. Luyken, C., Blümcke, I., Fimmers, R., Urbach, H., Wiestler, O.D., Schramm, J.: Supratentorial Ganglio-gliomas: Histopathologic Grading and Tumor Recurrence in 184 Patients with a Median Follow-Up of 8 Years. Cancer July, 2004; 101: 146-155.

15. McConachie, N.S., Worthington, B.S., Conford, E.J., Balsitis, M., Kerslake, R.W., Jaspan, T.: Computed Tomography and Magnetic Resonance in the Diagnosis of Intraventricular Cerebral Masses (review article). Br J Radiol 1994; 67: 223-243.

16. Morris, H.H., Matkovic, Z., Estes, M.L., Prayson,

\section{Comentario al artículo: Ganglioglioma with lytic skull lesions: a case report de Gurkanlar y cols.}

En este artículo se describe un caso de ganglioglioma en una paciente de 49 años de edad, con la peculiaridad de que este tumor producía imágenes de osteolisis en la bóveda craneal. Como principal motivo para la publicación, los autores refieren que su observación es el primer caso de la literatura de un paciente adulto en el que un ganglioglioma produce lesiones osteolíticas en la bóveda craneal, por lo que este tumor debe entrar en el diagnóstico diferencial de las lesiones osteolíticas craneales. En nuestra opinión se trata de una observación curiosa, pero el hecho de que un ganglioglioma se asocie a osteolisis craneal, tal vez no deba ser considerado como una observación excepcional. Es bien conocido que los gangliogliomas pueden localizarse superficialmente en el cerebro y que ocasionalmente crecen
R.A., Comair, Y.G., Turnbull, J., Najm, I., Kotagal, P., Wyllie, E.: Ganglioglioma and Intractable Epilepsy: Clinical and Neurophysiologic Features and Predictors of Outcome After Surgery. Epilepsia 2000; 41: 65-70.

17. Okamoto, Y., Hayashi, T., Harada, K., Shojima, K., Utsunomiya, H., Maehara, F., Yamamoto, M.: Ganglioglioma in a Child- Report of a Case. No Shinkei Geka. June,1986; 14: 857-863.

18. Perkins, O.C.: Gangliogliomas. Arch Pathol Lab Med. 1926; 2: 11-17.

19. Suzuki, H., Otsuki, T., Iwasaki, Y., et al.: Anaplastic Ganglioglioma with Sarcomatous Component: An Immunohistochemical Study and Molecular Analysis of p53 Tumor Supressor Gene. Neuropathology 2002; 22: 40-47.

20. Tampieri, D., Moumdjian, R., Melanson, D., Either, R.: Intracerebral gangliogliomas in patients with partial complex seizures. CT and MR imaging findings. AJNR 1991; 12: 749755.

21. Wolpert, S., Barnes, P.: MRI in Pediatric Neuroradiolgy. $1^{\text {st }}$ edition. St. Louis: Mosby-Year Book, 1992.

22. Zentner, J., Wolf, H.K., Ostertun, B., Jufnagel, A., Campos, M.G., Solymosi, L., et al.: Gangliogliomas: Clinical, Radiological and Histopathological Findings in 51 Patients. J Neurol Neurosurg Psychiatry 1994; 57: 1497-1502.

Gurkanlar, D.; Kocak, H.; Yucel, E.; Aciduman, A.; Gunaydin, A.; Ekinci, Ö.; Keskil, S.: Ganglioglioma with lytic skull lesions: a case report. Neurocirugía 2007; 18: 123-127.

Corresponding address: Doğa Gürkanlar M.D. Mustafa Kemal Universitesi. Rektörlük Konutu No: 6 Antakya. Turkey en el espacio subaracnoideo. No obstante, la duramadre suele representar una barrera para su crecimiento, al igual que ocurre en el caso de los astrocitomas exofíticos, y por ello, creemos que, posiblemente, lo más raro de este caso es la invasión dural y el crecimiento epidural de este peculiar tumor de tipo glioneuronal. Por otra parte, la posibilidad de que los gangliogliomas se asocien a lesiones óseas de la bóveda craneal está claramente descrita en textos clásicos, como el tratado de Patología de Tumores del Sistema Nervioso de Russell y Rubinstein ${ }^{1}$ donde se puede leer que "...II the tumor es located superficially, there may be erosive changes of the adjacent calvarium" $\mathrm{y}$ de hecho, los autores ya hacen referencia en la discusión a casos de gangliogliomas infantiles con afectación ósea craneal. 
Igualmente, en el libro que recoge la clasificación actual de la OMS de tumores del Sistema Nervioso², se señala que "scalloping of the calvarium may be seen adjacent to superficially located cerebral gangliogliomas". Además, la posibilidad de que los gangliogliomas se presenten como masas extra-axiales, de forma análoga a los meningiomas, incluso con vascularización a expensas de arterias meníngeas, ha sido documentada no hace mucho tiempo por Siddique y cols. ${ }^{3}$, por lo que es lógico aceptar que cuando un tumor de este tipo, cuya muy lenta evolución es característica, se localiza superficialmente, adyacente a la bóveda craneal, pueda asociarse a alteraciones óseas que se traduzcan radiológicamente por imágenes de aspecto osteolítico.

\section{Bibliografía}

1. Bigner, D.D.; Mc Lendon, R.E.; Bruner, J.M. Russell \& Rubinstein's Pathology of Tumors of the Nervous System. Arnold, London, 1998. p. 497.

2. Nelson, J.S.; Bruner, J.M.; Wiestler, O.D.; Vandenberg, S.R.: Gangliogliomas and gangliocytoma. In: Tumours of the Nervous System. Pathology and Genetics. World Health Organization Classification of Tumours. Kleihues P, and Cavenee WK Eds. IARC Press, Lyon, 2000. p. 96.

3. Siddique, K.; Zagardo, M.; Gujrati, M.; Olivero, W. Ganglioglioma presenting as a meningioma: case report and review of the literature. Neurosurgery 2002; 50: 1133-1136.

J. Vaquero

Madrid 